\title{
Review Article \\ Oxidized Extracellular DNA as a Stress Signal in Human Cells
}

\author{
Aleksei V. Ermakov, ${ }^{1}$ Marina S. Konkova, ${ }^{1}$ Svetlana V. Kostyuk, ${ }^{1}$ \\ Vera L. Izevskaya, ${ }^{1}$ Ancha Baranova, ${ }^{1,2}$ and Natalya N. Veiko ${ }^{1}$ \\ ${ }^{1}$ Research Centre for Medical Genetics, Russian Academy of Medical Sciences, Mosskvorechie street 1, Moscow 115478, Russia \\ ${ }^{2}$ Center for the Study of Chronic Metabolic Diseases, School of System Biology, George Mason University, Fairfax, VA 22030, USA \\ Correspondence should be addressed to Ancha Baranova; abaranov@gmu.edu
}

Received 8 December 2012; Accepted 27 January 2013

Academic Editor: Meera Ramanujam

Copyright (C) 2013 Aleksei V. Ermakov et al. This is an open access article distributed under the Creative Commons Attribution License, which permits unrestricted use, distribution, and reproduction in any medium, provided the original work is properly cited.

\begin{abstract}
The term "cell-free DNA" (cfDNA) was recently coined for DNA fragments from plasma/serum, while DNA present in in vitro cell culture media is known as extracellular DNA (ecDNA). Under oxidative stress conditions, the levels of oxidative modification of cellular DNA and the rate of cell death increase. Dying cells release their damaged DNA, thus, contributing oxidized DNA fragments to the pool of cfDNA/ecDNA. Oxidized cell-free DNA could serve as a stress signal that promotes irradiation-induced bystander effect. Evidence points to TLR9 as a possible candidate for oxidized DNA sensor. An exposure to oxidized ecDNA stimulates a synthesis of reactive oxygen species (ROS) that evokes an adaptive response that includes transposition of the homologous loci within the nucleus, polymerization and the formation of the stress fibers of the actin, as well as activation of the ribosomal gene expression, and nuclear translocation of NF-E2 related factor-2 (NRF2) that, in turn, mediates induction of phase II detoxifying and antioxidant enzymes. In conclusion, the oxidized DNA is a stress signal released in response to oxidative stress in the cultured cells and, possibly, in the human body; in particular, it might contribute to systemic abscopal effects of localized irradiation treatments.
\end{abstract}

\section{Introduction}

The effect of information transfer from the irradiated cells (target cells) to adjacent, nonirradiated ones is known as the bystander effect (BE). The BE was shown for a number of damaging agents of both physical and chemical nature, in many types of eukaryotic cells, and covers a variety of physiological effects including the genomic instability, the cell death, and/or the adaptive response (AR) [1]. As a result of adaptive response brought about by low-dose ionizing radiation, the cells develop resistance to further irradiation at higher (damaging) doses. Both reactions ( $\mathrm{AR}$ and $\mathrm{BE}$ ) are closely interconnected biologically and have many similarities and characteristic features [2-5]. Interestingly, both $\mathrm{AR}$ and $\mathrm{BE}$ may be transferred to intact cells through their exposure to the media conditioned by exposed cells $[6,7]$. Importantly, the development of particular variant of cellular response depends on the amount of irradiation, amount of cells, their tissue origin, and the stage of the cell cycle. In some experimental studies, the response of bystander cells might not be adaptive [1-7].
For the first time, the intercellular signaling was experimentally demonstrated on Chinese hamster cell culture [8]. Following irradiation of not more than $1 \%$ of cellular nuclei, the authors observed increased frequency of sister chromatids exchanges in $20-40 \%$ of the cultured cells. It is generally accepted that there are three possible pathways of signal transfer from the irradiated cell to the "bystander" cell: through the direct cellular contact with the formation of common membranous structures, through interaction involving the gap junctions or via the signals released to the culture medium of the irradiated cells. The third pathway is typical for the $\mathrm{BE}$ induced by radiation with low Linear Energy Transfer (LET) [9]. Many candidate molecules, mainly the soluble proteins, have been proposed as mediators of the bystander signaling between treated cells and bystander cells. All these data had been reviewed in details previously [10-17].

In course of our studies, we thoroughly evaluated an idea of existence of certain intrinsic cellular factor that is released from the dying cells, thus, causing the development of the bystander effect. The present work is a brief overview of our 
recent findings concerning the possible role of extracellular DNA oxidation in the development of the adaptive response and bystander effect, as triggered in human cells by exposure to oxidative stress [18-35].

\section{Oxidative Stress Induces the Oxidation of Cellular DNA}

Many chronic diseases are accompanied by an increase in overall oxidation of genomic DNA. Under oxidative stress, the DNA bases are prone to oxidation, with the most common products being the thymidine glycol and 8-hydroxy$2^{\prime}$-deoxyguanosine (8-oxodG). In fact, the 8 -oxodG is the most widely used "marker" for oxidative DNA damage. The 8-oxodG is formed in DNA either via direct oxidation or can be incorporated into DNA by DNA polymerase as a modified base drawn from the nucleotide pool $[36,37]$.

Previously published studies have reported the frequency of 8-oxodG in genomic DNA (gDNA) samples. For example, gDNA extracted from cultured cells $[38,39]$ contains approximately from 0.1 to 0.58 -oxodG per $10^{6}$ nucleotides, while normal breast tissue from cancer patients has significantly higher levels of oxidative DNA damage-up to 258 oxodG per $10^{6}$ nucleotides [40]. Most of the results clearly indicate higher steady-state levels of modified DNA bases in cancerous tissues than in their cancer-free surrounding tissues. The level of oxidative modification of cellular DNA may serve as a predictive marker of cancer development [4143]. For example, in breast carcinomas, 8-oxodG levels have been reported as being 8 to 17 times higher as compared with nonmalignant breast tissue [44-46]. Additionally, it was shown that an exposure of the MCF-10A cells to doxorubicin leads to a significant increase in the levels of eleven different oxidized forms of DNA bases [47].

The genomes of prostatic carcinoma cell lines LNCaP, DU145, and PC3 contain between 3 and 4.5 8-oxodG/10 ${ }^{6}$ nucleotides, while genomic DNA extracted from the prostatic tissue of young men contains approximately $\sim 50$ 8-oxodG $/ 10^{6}$ nucleotides $[48,49]$. With age, these levels increase to up to $\sim 75$ 8-oxodG $/ 10^{6}$ nucleotides. Noncancerous prostatic tissue of prostatic carcinoma patients contains $\sim 90$ 8-oxodG $/ 10^{6}$ nucleotides, while in prostatic carcinoma cells these amounts increase up to $\sim 120$-oxodG $/ 10^{6}$ nucleotides [48, 49]. Interestingly, in prostatic carcinoma cells, the levels of 8-oxodG could be induced by exposure to supraphysiological concentrations of dihydrotestosterone [50].

Human ovarian tissue contains approximately 1.38 oxodG per $10^{6}$ nucleotides, while in advanced epithelial ovarian carcinoma these levels increase to 2.28 -oxodG $/ 10^{6}$ nucleotides [51]. In uterine myomas, the levels of 8-oxodG are higher than those in underlying myometrium ( 3-4 8-oxodG and 28 -oxodG $/ 10^{6}$ nucleotides, resp.) and correlate with the size of the tumor [52].

Two-three-fold increases in levels of 8-oxodG were observed in lung carcinoma as compared to cancer-free surrounding lung tissues [53]. Among Noncancerous lung samples, the lung tissue removed from smokers had the highest increases of modified bases above the control levels and the highest overall amounts of 8-oxodG [54].

DNA extracted from PBMCs of healthy donors contains between 1 and 1.38 -oxodG bases per $10^{6}$ nucleotides [5560]. In PBMCs of cancer patients, the content of 8-oxodG increases to $1.5-1.8$ modified bases per $10^{6}$ nucleotides $[45,55$, $56,59,60]$. Lymphocyte DNA from lung cancer patients had 1.7-fold higher levels of 8-oxodG compared to the controls. The difference was especially evident in current smokers [61]. The levels of 8-oxodG in DNA extracted from leukocytes of patients with Leber's hereditary optic neuropathy were 3.3 bases per $10^{6}$ nucleotides [62]. Similar increases were observed in DNA of Parkinson's disease and multiple sclerosis patients $[63,64]$. Increased levels of 8-hydroxyadenine, 8oxodG, thymine glycol, Fapy-guanine, 5-hydroxymethyl-2' deoxyuridine, and Fapy-adenine were observed in brains of patients with Alzheimer's disease [65]. The mean levels of 8 -oxodG in neurons were 10 times higher in elderly "pooroutcome" schizophrenia than in control DNA samples [66]. A marked elevation of 8-oxodG in leukocyte DNA samples obtained from patients with chronic renal failure [67-69] and Fanconi anaemia [70] was also reported. In germ-line cells of men with type 1 diabetes, the content of 8-oxodG is increased up to 9 modified bases per $10^{6}$ [71]. In patients with coronary artery disease, the levels of oxidative DNA damage correlate with the severity of the disease $[72,73]$. Moreover, both in rats and in humans, the 8 -oxodG content in DNA positively correlates with the age [74-79].

In the majority of studies, the levels of 8-oxodG were experimentally measured in total DNA extracted from the lysed cells or tissue samples. However, it is likely that some DNA molecules within the cell are substantially more prone to oxidative damage, for example, the mitochondrial DNA. As compared to the genomic DNA, the mtDNA shows substantial enrichment in GC nucleotide pairs; therefore, oxidized mtDNA may be disproportionate contributor to evaluated levels of 8-oxodG content in total DNA samples [80-82]. It should be noted that GC-rich fragment within genomic DNA tends to accumulate oxidative damage as well. One example of the preferentially oxidized DNA locus is the transcribed area of the ribosomal repeats [83].

All of this indicates that oxidation of DNA takes place in human cells as it is commonly observed both in health and disease. In cells undergoing oxidative stress and in chronic diseases, the levels of oxidative modifications of DNA increase substantially.

\section{Extracellular DNA Is Enriched with the Oxidized Genomic DNA}

The term "cell-free circulating DNA" (cfDNA) was coined for DNA fragments that could be collected from plasma, serum, or other bodily fluids. CfDNA circulates throughout the bloodstream of both healthy people and patients with various diseases. DNA isolated from cell-free supernatants of cells cultivated in vitro is known as extracellular DNA (ecDNA) [84]. EcDNA is found in the culture medium of both intact cells and cells exposed to various types of oxidative stress. 
The most widely accepted hypothesis is that the main sources of cfDNA/ecDNA are the dead cells [85]. Another hypothesis suggests that cfDNA/ecDNA could be actively excreted into the medium by living cells [86]. Recently, cfDNA got recognition as a promising biomarker for noninvasive diagnostics and monitoring of various diseases [84]. However, the biological role of cfDNA in normal or pathological conditions remains unclear. The functionality of these circulating DNA fragments is determined by cfDNA properties, for example, its concentration in the blood plasma and the level of oxidative modification that can be approximated by its average content of 8-oxodG.

In plasma of healthy individuals, total cfDNA concentrations vary from 1 to $\sim 100 \mathrm{ng} / \mathrm{mL}$. These concentrations increase with age or in presence of various stressful conditions, for example, pregnancy, intensive exercise, or strong emotions as well as when malignancy or other chronic pathology is diagnosed. In plasma samples of patients with cancer or critical cardiovascular conditions, the concentrations of cfDNA increase up to $1000 \mathrm{ng} / \mathrm{mL}$ [84-92].

Oxidative stress is known to cause the DNA damage. The cells with the most damaged DNA die either by necrosis or by apoptosis. The oxidized DNA released from the dying cells is likely the most prominent contributor to cfDNA/ecDNA pool. Therefore, it is likely that cfDNA/ecDNA would contain larger amounts of 8-oxodG as compared to that in cellular DNA.

The comparative data describing 8-oxodG levels in cfDNA/ecDNA and in cellular DNA extracted from the same organism or cell culture are sparse. Some authors point that the levels of 8-oxodG in serum samples profiled by ELISA and by HPLC differ substantially $[93,94]$. In our opinion, most likely explanation of these discrepancies is the fact that, in serum, 8-oxodG circulates both as free nucleoside and as part of oxidized cfDNA fragments. ELISA quantifies total concentrations of 8-oxodG that, in healthy donors, is around $0.3-5.9 \mathrm{ng} / \mathrm{mL}$ of plasma/serum [95-99] while HPLC-based techniques detect only free 8-oxodG that is present in plasma/serum samples at concentrations of $0.013-$ $0.022 \mathrm{ng} / \mathrm{mL}[93,94,100-103]$. One may calculate the minimal background content of 8 -oxodG embedded in cfDNA fragments by subtracting bound 8 -oxodG concentrations from total 8 -oxodG concentrations $(0.3-0.022 \approx 0.28 \mathrm{ng} / \mathrm{mL})$. Given that maximal observed concentration of cfDNA is at $\sim 1000 \mathrm{ng} / \mathrm{mL}$, the minimal content of 8 -oxodG in cfDNA could be estimated as at least 280 8-oxodG bases per $10^{6}$ nucleotides, the figure that substantially exceeds estimated 8oxodG content in DNA of living cells.

In our study we demonstrated that cfDNA/ecDNA is substantially enriched in 8-oxodG as compared to cellular DNA, up to 220-3000 8-oxodG per $10^{6}$ nucleotides. The degrees of enrichment were significant when cfDNA/ecDNA and cellular DNA samples were evaluated for cancer or myocardial infarction patients, for primary tumor cells, as well as for endotheliocytes cultures that were irradiated or treated with peroxide $[30,33]$.

In addition to preferential enrichment of cfDNA pools with oxidized DNA of dying cells, the contents of 8-oxodG in cfDNA may depend on well-known phenomenon of somewhat slowed down degradation of GC-rich DNA fragments in human serum as compared to AT-rich fragments $[21,92,104-106]$. Moreover, under the condition of oxidative stress, an increase in proportions of mitochondrial DNA within cfDNA was documented [80-82]. This process is relevant as mitochondrial DNA, on average, contains larger amounts of 8-oxodG as compared to genomic DNA [107].

\section{Oxidized cfDNA/ecDNA Is a Stress Signal}

The cfDNA extracted from blood plasma of patients with high oxidative stress levels can significantly influence the physiological activity of intact cells. For example, when primary endotheliocytes (HUVECs) were exposed to cfDNA samples obtained from patients with hypertension and atherosclerosis, their NO contents substantially decreased, while the DNA samples obtained from healthy donors have no effect of NO release $[28,29]$. In electrically paced cultures of ventricular neonatal rat myocytes, an exposure to the cfDNA of patients with acute myocardial infarction has produced a decrease in the frequency of contraction [108]. The cfDNA from ischemic rats decreased the levels of ROS production in neuronal cultures [32]. Both ecDNA collected from the media of primary tumor cells cultures and cfDNA extracted from plasma of cancer patients have influenced ROS production in mesenchymal stem cells (MSCs) [33]. Importantly, cfDNAs extracted from blood of myocardial infarction and rheumatoid arthritis patients stimulate the expression of DNA sensor toll-like receptor 9 (TLR9) in MSCs, while an exposure to gDNA did not influence TLR9 levels [35].

As observed both in endothelial cells and in MSCs, the samples of the genomic DNA that were oxidized in vitro with either $\mathrm{H}_{2} \mathrm{O}_{2}$ or Methylene Blue $\left(\mathrm{gDNA}^{\mathrm{OX}}\right.$ ) evoke responses that are similar to those of cfDNA/ecDNA. In endothelial cells, exposure to gDNA ${ }^{\mathrm{OX}}$ stimulated an expression of NOX4 and suppresses eNOS, therefore, augmenting net production of ROS and decreasing the levels of NO [34]. In mesenchymal stem cells, increased concentrations of gDNA ${ }^{\text {OX }}$ and oxidized cfDNA/ecDNA stimulated a rapid increase in ROS synthesis and upregulated expression levels of the NF-E2-related factor-2 (NRF2), that plays a central role in antioxidantresponse-element- (ARE-) mediated induction of phase II detoxifying and antioxidant enzymes along with a number of antioxidant response genes [33].

In murine macrophages, the treatment with GC-rich DNA fragments that are also enriched in 8-oxodG stimulates secretion of TNF- $\alpha$ [109]. The treatment of experimental animals with $\mathrm{gDNA}^{\mathrm{OX}}$ produced inflammation and induced production of $\mathrm{DNA}^{\mathrm{OX}}$-specific antibodies [110, 111].

An analysis of the data concerning cfDNA/ecDNA properties and the effects it produces on mammalian cells allowed us to suppose that ecDNA of irradiated cells $\left(e c D N A^{\mathrm{R}}\right)$ may somehow influence the other nonirradiated cells within the cell cultures thus acting as a soluble stress-signalization factor in a radiation-induced $\mathrm{BE}$. Our further studies confirmed this assumption, having for the first time demonstrated the significance of the bystander signaling with participation of 
oxidized extracellular DNA for human cells exposed to lowdose irradiation [22-27, 30, 31, 34].

\section{Oxidized DNA-Dependent Signaling in Radiation-Induced Bystander Effect}

5.1. $E c D N A^{R}$ from the Irradiated Cells Is the Signaling Factor in BE. The main source of the ecDNA is the dead or dying cells. In a number of recent studies we demonstrated that ionizing low-LET irradiation increases the rate of apoptosis in various cell cultures. It seems that some subpopulations of cultured cells possess an increased sensitivity to apoptosis that may be evoked by irradiation at low doses. To pursue this hypothesis, we isolated and characterized the population of irradiation-sensitive human lymphocytes. This subpopulation was rich in large-size activated cells, could spontaneously incorporate $(3 \mathrm{H})$-thymidine, had increased radiosensitivity, and decreased activity of the excision repair, as well as a high level of spontaneous chromosomal aberrations and apoptosis, all these increasing after irradiation [112].

In our study, the apoptosis levels were assessed by evaluating the number of double-strand breaks (DSBs) in the genomic DNA by using a technique based on visualization of phosphorylated protein $\mathrm{H} 2 \mathrm{AX}(\gamma$-foci) in the site of rupture. Accumulation of $\gamma$-foci in large amounts is indicative of the apoptosis [113]. Both in HUVECs and MSCs [26, 30], an irradiation is followed by accumulation of $\gamma$-foci. In peripheral blood lymphocytes, an irradiation leads to an increase in the activity of caspase-3, one of the main cysteine proteases activated in apoptosis [20, 22, 23]. After irradiation, the dying cells release the fragments of chromatin, thus, contributing to the pool of ecDNA/cfDNA.

The electrophoretic analysis shows that the size of ecDNA fragments produced by cultured cells varies from 180 to $20,000 \mathrm{bp}$, with a predominance of the fragments 180 and $360 \mathrm{bp}$ in size that corresponds to mono- and dinucleosomes, respectively $[20,22,30]$. After irradiation, the concentration of longer fragments decreases and that of the short ones increases. EcDNA of irradiated cells contained significantly larger amounts of oxidation marker 8-oxodG than ecDNA of control (nonirradiated) cells or cellular DNA of irradiated cells [30].

The studies of the bystander effect were performed in various cell types, including G0-lymphocytes of peripheral blood [22-24, 27], HUVECs [30, 34], and MSCs of adipose tissue $[26,31]$. Ionizing radiation is known to render both a direct effect on cellular structures via hitting with an energy quantum or particle and an indirect effect mediated by free radicals [114]. The cellular response to irradiation depends on many factors, but the most important of them is a substantial increase in the levels of ROS. Ionization results in synthesis of ROS. The process of ROS formation after exposure to radiation takes place within the time frame of several seconds to 2-5 minutes [115]. In turn, ROS induces multiple lesions in cellular DNA, including the ruptures of desoxyribose rings, the appearance of apurinic and apyrimidinic sites, singleand double-strand breaks, DNA protein cross-links, and formation of oxidized bases [116-122].
Importantly, in control (nonirradiated) cells, the ecDNA collected from the media conditioned by irradiated cells stimulates an increase on the ROS production to approximately the same degree as DNA oxidized in vitro or small doses of irradiation [34]. This indicates that ecDNA released from dying irradiated cells may serve as a stress signal that conveys a bystander effect, while ecDNA of nonirradiated cells is not a stress signal as it does not induce ROS synthesis in control cells.

Various parameters of the target cell and bystander cells are being analyzed in regards to irradiation and its effects. The most commonly studied group of such parameters includes a number of cytological characteristics of cellular nuclei, including the shape of the nucleus as well as FISH-defined descriptors of chromosomal territories, that is, positions of chromosome loci as they relate to the centre of the nucleus and to each other [18]. One of the known markers for irradiation-induced chromatin rearrangement is a position of pericentromeric loci of chromosome 1 (1q12). When effects of irradiation at a dose of $10 \mathrm{cGy}$ were compared to those of direct oxidative stress causing agent $\mathrm{H}_{2} \mathrm{O}_{2}$, of exposure to ecDNA extracted from the media conditioned by irradiated cells $\left(\mathrm{ecDNA}^{\mathrm{R}}\right)$ or of exposure to ecDNA extracted from $\mathrm{H}_{2} \mathrm{O}_{2}$-treated cells (ecDNA ${ }^{\mathrm{H}_{2} \mathrm{O}_{2}}$ ), similar structural rearrangements of chromatin were observed. Particularly, there was a decrease of the proportion of cells with the perimembranous location of loci at 1q12 a nd an increase in the proportion of the cells with central nuclear localization of these loci. It was also shown that exposure induces approximation of the loci 1q12 of homologous chromosomes 1 within the space of the cellular nucleus $[20,22,23,26,27,30,31]$. Additionally, the nuclei of both HUVECs and adipose-derived MSCs acquired a compacted, more spherical shape [26, 30, 31]. All these effects were primarily dependent on an increase in the production of ROS that was approximately to the same degree stimulated by irradiation, $\mathrm{H}_{2} \mathrm{O}_{2}$, ecDNA ${ }^{\mathrm{R}}$, or ecDNA $\mathrm{H}_{2} \mathrm{O}_{2}$. When an inhibitor of ROS, $\alpha$-tocopherol, was added to the media, all these effects were blocked.

Irradiation-dependent chromosomal loci relocation effects were confirmed by other researchers. The transposition of chromatin regions within the nucleus is accompanied by DNA repair [123]. Moreover, within the nuclei of irradiated cells, the convergence of homologous chromosomes in the sites of DSB emergency repair has been observed [124]. The structural rearrangement of chromatin promotes the launch of gene expression program that is necessary for the development of the adaptive response, with the approximation of chromosomes themselves being an event favorable for further elimination of DSBs through the repair associated with chromosomal homologous recombination (HR) or nonhomologous end joining (NHEJ). The irradiation-dependent chromosomal loci transposition had been demonstrated in lymphocytes [18-20, 22-24, 27], human endothelial cells [30], mesenchymal stem cells $[26,31]$, and in cancer stem cells of the mammary gland [25], thus, strongly suggesting that these effects are widespread. It should be mentioned that when irradiated cells fail to transpose the marker loci following 
irradiation, elevated levels of cell death are observed already at very low doses of ionizing radiation [25].

The structural transformations of chromatin mentioned above are accompanied by activation of ribosomal gene transcription which may be evidenced by staining the cellular preparations with silver nitrate or assessing rRNA levels by quantitative PCR. ROS-dependent induction of adaptive response implies an increase in the synthesis of proteins, primarily of repair proteins and those necessary for reorganization of the genome. Therefore, an enhanced transcription of ribosomal genes and an elevated amount of rRNA in ROS stimulated cell is to be expected $[19,23,27,30]$.

An increase in F-actin polymerization was observed both in irradiated cells and in ecDNAR-treated bystander cells. Alterations in the architecture of the cellular cytoskeleton observed after exposure to X-ray radiation and ecDNAR are similar as well [30]. Our findings suggest that alterations in the architectonics of the cellular cytoskeleton appear both after exposure to X-ray radiation and ecDNA ${ }^{\mathrm{R}}$ [30].

The study also showed that addition of ecDNA ${ }^{\mathrm{R}}$ into the growth medium of intact endotheliocytes leads to a decrease in the number of cells with single $\gamma$-foci and to a considerable increase in the number of apoptotic cells in the population [30]. Similar effects were observed when cells were irradiated in low doses. This study supports the findings of other authors having shown that an incubation medium of irradiated cells induces the initial stages of the apoptotic cascade in bystander cells. In these experiments, an induction of apoptosis in bystander cells was also accompanied by an elevation in the content of ROS within 6-hour time frame [125].

The mirror-like patterns of the effects described above and seen in both treated and bystander cells point to the transfer of a stimulus from irradiated to bystander cells. An addition of the ecDNA produced by control (nonirradiated) cells to the medium of bystander cells does not produce any of the effects described above, and no adaptive response is observed. Interestingly, after the hydrolysis by DNAse I, the ecDNA $^{\mathrm{R}}$ produced by irradiated cells loses its stress signal properties and its ability to evoke an adaptive response [20, 22].

It is also important to note that BE is not cell-type specific. The media conditioned by irradiated cells of one cellular type conveys the bystander effect to other kinds of bystander cells exposed to this media [24]. Similarly, ecDNA ${ }^{\mathrm{R}}$ extracted from the growth medium of irradiated endotheliocytes conveys an adaptive response in the bystander MSCs and vice versa (data not published).

\subsection{EcDNA Signal Propagates with Aid of Oxidative Stress.} The data described above indicate that the cascade of sequential events in ecDNA-signaling may be as follows:

Irradiation $\rightarrow$ [primary oxidative stress $\rightarrow$ oxidation of gDNA $\rightarrow$ apoptosis of some portion of irradiated cells $\rightarrow$ release of oxidized ecDNA ${ }^{\mathrm{R}} \rightarrow$ reception of the ecDNA ${ }^{\mathrm{R}}$ signal by the bystander cells $\rightarrow$ secondary oxidative stress] $\rightarrow$ oxidation of gDNA in the bystander cells $\rightarrow$ apoptosis of some portion of bystander cells $\rightarrow$ release of oxidized ecDNA, and so forth.
In this cascade, the oxidative stress propagates from irradiated cells to bystander cells (Figure 1). The secondary oxidative stress that is evoked in intact bystander cells occurs after an interaction of the oxidized ecDNA ${ }^{\mathrm{R}}$ with its receptors, or oxidized DNA sensors, that must be present on the surface or inside the bystander cells. The possible candidates for these sensors are the transmembrane proteins of the toll-like receptor family, namely, TLR9 [126]. Being transmembrane receptors, they contain a repetitive LRR domain capable of binding the ligand and a highly conservative intracellular region that ensures the interaction between the receptors and the molecules of the downstream signaling pathway, for example, an adapter protein MyD88. It is well known that the DNA fragments with unmethylated CpG motifs may serve as TLR9 ligands. In this cascade, the formation of the "DNA-TLR9" complex initiates the cellular signaling pathway that, in turn, leads to an activation of the transcription factor NF- $\kappa$ B, which in many different ways augments the biosynthesis of ROS. For example, TLR9 ligation may be followed by an increase in intranuclear production of $\mathrm{NO}^{\circ}$ $[127,128]$ or $\mathrm{O}_{2}{ }^{-}$radical [129]. In human monocytes, the binding of CpG-DNA to TLR9 is accompanied by secretion of both $\mathrm{NO}^{\circ}$ and ROS [130], while in neutrophils it leads to the production of peroxynitrite [127]. The slow-acting oxidants $\mathrm{O}_{2}{ }^{--}$, $\mathrm{NO}$, and $\mathrm{H}_{2} \mathrm{O}_{2}$ are produced by sequence of metal ion-dependent enzymatic reactions that, in turn, may give rise to highly reactive compounds: $\mathrm{OH}^{*}$ and hypohalogenous acids, as well as $\mathrm{1O}_{2}, \mathrm{NO}^{\circ}$, and $\mathrm{NO}_{2}{ }^{\circ}$. During bystander effect, possible participation of the Fenton reaction is evidenced by the studies that showed that the radiation-induced adaptive response depends on the production of the signal molecule NO [11, 131]. Interestingly, in macrophages, the substitution of dG with 8-oxodG in the DNA ligand for TLR9 is accompanied by a significant increase in TNF- $\alpha$ cytokine [109]. In other words, an oxidized DNA seems to be a stronger TLR9stimulating ligand than nonoxidized DNA.

In our opinion, oxidized DNA is one of the components of damage-associated molecular pattern molecules (DAMPs). Its effects can potentially increase when exposure to oxidized DNA is concomitant with the presence of other DAMPs. It might be that effects of oxidized DNA are at least in part mediated by high mobility group box 1 (HMGB1) protein whose expression is enhanced after irradiation. HMGB1 functions as an extracellular damage-associated molecular pattern molecule that promotes inflammation, cellular differentiation, survival, and migration [132-136]. HMGB1 was shown as an essential component of DNA-containing complexes that stimulated cytokine production through a TLR9-MyD88 pathway. Extracellular HMGB1 accelerates the delivery of CpG-DNAs to its receptor, leading to a TLR9-dependent augmentation of IL-6, IL-12, and TNF $\alpha$ secretion [137-143]. There is evidence that HMGB1 protein binds preferentially to damaged DNA [144]. It was also shown that extracellular histones directly interact with TLR9 and enhance DNAmediated TLR9 activation in immune cells [145].

In the populations of irradiated lymphocytes, the expression of TLR9 gene and the main adaptor of its signaling pathway MyD88 increase severalfold [27]. In order to confirm 


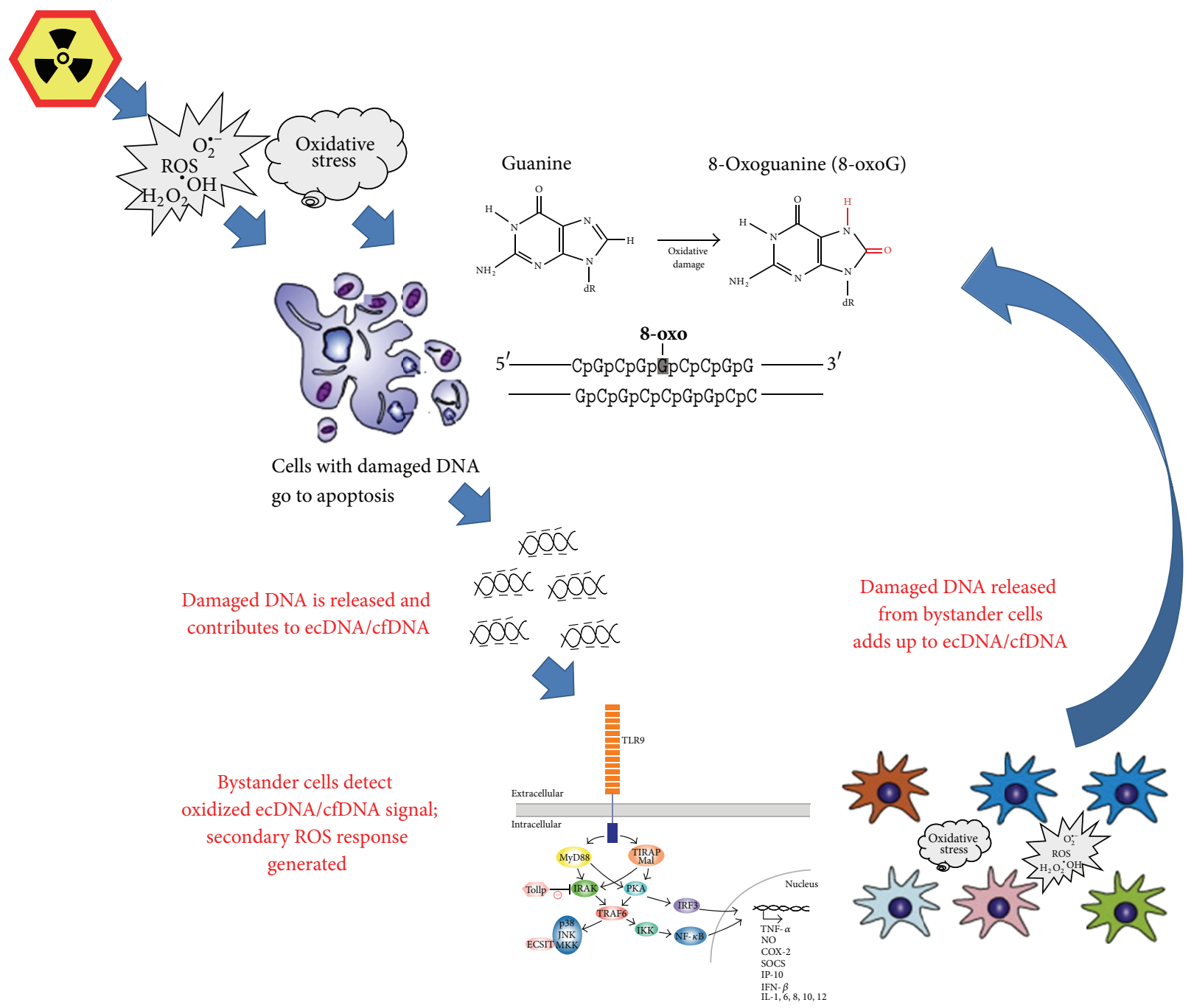

FIGURE 1: The proposed mechanisms for the propagation of the stress signal from irradiated cells to bystander cells. In this scheme, the 8oxo-dG serves as a model example of DNA lesion that turns DNA fragments into the stress signal; it should be noted that other types of DNA lesions may be recognized as well. The central player that ensures amplification of the signal in this cascade is the oxidative stress. The secondary oxidative stress evoked in intact bystander cells occurs after an interaction of the oxidized ecDNA with the receptors, or oxidized DNA sensors, that must be present on the surface or inside the bystander cells. One possible candidate for oxidized DNA sensor is toll-like receptor TLR9.

participation of TLR9 in bystander DNA-signaling during the development of $\mathrm{BE}$, we blocked these receptors by two inhibitors, a specific oligonucleotide suppressor that provides considerable competition in binding the ligand with the receptor or nonspecific inhibitor chloroquine that changes the $\mathrm{pH}$ value in endosome and makes the formation of the DNA-receptor complexes unlikely. When TLR9 pathway was blocked, there were no substantial changes in the localization of 1q12 loci and in the level of NO in bystander cell exposed to ecDNA $^{\mathrm{R}}$ from irradiated cells. However, both an increase in the levels of ROS production and an activation of ribosomal genes still took place $[23,30,34]$. These findings suggest that radiation-induced bystander effect may be propagated through more than one molecular pathway. In addition to oxidized DNA-stimulated TLR9 receptors, other sensors, whose activation leads to the changes in ROS and rRNA expression levels but does not lead to transposition of the analyzed chromosomal loci in the nucleus, may be involved. Evidence pointing at existence of toll-like-receptor-independent stress signal transfer pathways was previously demonstrated by other authors [146, 147], including cytoplasmic DNAdependent STING, AIM2, RIG-1, and DAI sensor pathways [148]. Some of these pathways are directly linked to apoptosis induction by ecDNA fragments (AIM2); others stimulate pro- and anti-inflammatory cytokine synthesis. It is possible that ecDNA ${ }^{\mathrm{R}}$ may be uptaken to penetrate into the cytoplasm and activate those pathways. It is also very well might be that eukaryotic cells contain a variety of the molecules that sense the damage in cell-free DNA, and that these cells may differentially respond to a variety of oxidized or otherwise 
modified DNA bases. The reception of ecDNA produced by irradiated cells warrants further investigations.

After exposure of human lymphocytes to X-ray radiation at a low dose, adaptive reaction develops within 4-6 hours. It is known that such response takes a few cell cycles [149, 150] even longer $[125,151,152]$. Although the persistence of irradiation effects has been described in the literature about 50 years ago, its mechanisms are still to be determined. However, it is very likely that one of the main components of the long-term process of irradiation response is the generation of ROS that may remain elevated for many cellular generations $[153,154]$. In our opinion, the oxidative stress may be maintained in cells after the initial irradiation event as a result of sustained activation of oxidized ecDNA-signaling pathway. This activation may be maintained by the fragments of oxidized ecDNA released from irradiated cells that die by apoptosis and release their damaged DNA into circulation or cell media. When the fragments of oxidized ecDNA interact with recipient "bystander" cells, it evokes secondary oxidative stress in some bystander cells. In turn, these bystander cells initiate apoptotic cascades that lead to further release of oxidized ecDNA. The mechanism described above takes into account previous observations that the daughter populations derived from irradiated cells retain an elevated level of ROS that play a substantial role in maintaining the adaptive response throughout cell generations [155].

\section{Conclusion}

Irradiation, chronic diseases, or other prooxidative stimuli and conditions lead to an increase in oxidative stress and in oxidation of cellular DNA. In case of apoptotic death of stressed cells, oxidized DNA ends up released in cell culture medium (ecDNA) or in circulation (cfDNA). In cultured cells, oxidized ecDNA serves as a stress signal that is transmitted from stressed (i.e., irradiated) cells to bystander cells. It is tempting to speculate that a similar process takes place in human body challenged with focused irradiation or suffering from chronic disease. In human cells, oxidized DNA induces additional synthesis of ROS. When ecDNA/cfDNA = dependent increase in ROS levels remains moderate, the bystander cells develop an adaptive response, that is, at least in part, due to an activation of the transcription factor NRF2, which is capable of inducing antioxidant expression program.

So far, no studies demonstrating that oxidized cfDNA may play a role in bystander effect in vivo were published. Effects of exposure to oxidized cfDNA should be taken into account when treating tumors with various ROS-producing agents and irradiation. As oxidized cfDNA released from the dying tumor cells enters the circulation, it is being carried to the distant organs, with its effects expected to be systemic. For example, the damaged DNA released from irradiated cells may be responsible for abscopal effects that are suspected to be depended on actions of immune system, in particular, the ones mediated by TLRs. It is possible that artificial modulation of concentration, GC-content, and the level of oxidation of cfDNA may improve clinical outcomes in patients with various chronic diseases accompanied by extensive cell death. The data summarized above indicate the necessity for further study of the effects of oxidized DNA in both in vitro and in vivo systems.

\section{Abbreviations \\ AR: $\quad$ Adaptive responses \\ BE: $\quad$ Bystander effect \\ DSBs: DNA double-strand breaks \\ EcDNA: Extracellular DNA \\ OS: $\quad$ Oxidative stress \\ ROS: $\quad$ Reactive oxygen species \\ HUVEC: Human umbilical vein endothelial cells \\ MSC: Mesenchymal stem cells.}

\section{Acknowledgments}

This work was supported by the RFBR (12-04-32081), by the Contract no. 8273 (August 27, 2012) under the call no. 20121.1-12-000-2008-067 of the Ministry of Education and Science of Russia, and by Thomas F. Jeffress and Kate Miller Jeffress Foundation Grant J-1023.

\section{References}

[1] M. Ojima, H. Eto, N. Ban, and M. Kai, "Radiation-induced bystander effects induce radioadaptive response by low-dose radiation," Radiation Protection Dosimetry, vol. 146, no. 1-3, pp. 276-279, 2011.

[2] F. Ballarini, M. Biaggi, A. Ottolenghi, and O. Sapora, "Cellular communication and bystander effects: a critical review for modelling low-dose radiation action," Mutation Research, vol. 501, no. 1-2, pp. 1-12, 2002.

[3] C. Mothersill and C. Seymour, "Radiation-induced bystander effects and adaptive responses-the Yin and Yang of low dose radiobiology?" Mutation Research, vol. 568, no. 1, pp. 121-128, 2004.

[4] B. R. Scott, "A biological-based model that links genomic instability, bystander effects, and adaptive response," Mutation Research, vol. 568, no. 1, pp. 129-143, 2004.

[5] M. Ko, X. Y. Lao, R. Kapadia, E. Elmore, and J. L. Redpath, "Neoplastic transformation in vitro by low doses of ionizing radiation: role of adaptive response and bystander effects," Mutation Research, vol. 597, no. 1-2, pp. 11-17, 2006.

[6] R. Iyer and B. E. Lehnert, "Low dose, low-LET ionizing radiation-induced radioadaptation and associated early responses in unirradiated cells," Mutation Research, vol. 503, no. 1-2, pp. 1-9, 2002.

[7] S. A. Mitchell, S. A. Marino, D. J. Brenner, and E. J. Hall, "Bystander effect and adaptive response in $\mathrm{C} 3 \mathrm{H} 10 \mathrm{~T} 1 / 2$ cells," International Journal of Radiation Biology, vol. 80, no. 7, pp. 465-472, 2004.

[8] H. Nagasawa and J. B. Little, "Induction of sister chromatid exchanges by extremely low doses of $\alpha$-particles," Cancer Research, vol. 52, no. 22, pp. 6394-6396, 1992.

[9] C. Mothersill and C. B. Seymour, "Cell-cell contact during gamma irradiation is not required to induce a bystander effect in normal human keratinocytes: evidence for release during irradiation of a signal controlling survival into the medium," Radiation Research, vol. 149, no. 3, pp. 256-262, 1998. 
[10] E. I. Azzam, S. M. de Toledo, and J. B. Little, "Stress signaling from irradiated to non-irradiated cells," Current Cancer Drug Targets, vol. 4, no. 1, pp. 53-64, 2004.

[11] H. Matsumoto, A. Takahashi, and T. Ohnishi, "Radiation-induced adaptive responses and bystander effects," Uchu Seibutsu Kagaku, vol. 18, no. 4, pp. 247-254, 2004.

[12] S. M. de Toledo and E. I. Azzam, "Adaptive and bystander responses in human and rodent cell cultures exposed to low level ionizing radiation: the impact of linear energy transfer," Dose Response, vol. 4, no. 4, pp. 291-301, 2006.

[13] T. K. Hei, H. Zhou, V. N. Ivanov et al., "Mechanism of radiationinduced bystander effects: a unifying model," Journal of Pharmacy and Pharmacology, vol. 60, no. 8, pp. 943-950, 2008.

[14] J. Rzeszowska-Wolny, W. M. Przybyszewski, and M. Widel, "Ionizing radiation-induced bystander effects, potential targets for modulation of radiotherapy," European Journal of Pharmacology, vol. 625, no. 1-3, pp. 156-164, 2009.

[15] K. M. Prise and J. M. O'Sullivan, "Radiation-induced bystander signalling in cancer therapy," Nature Reviews Cancer, vol. 9, no. 5, pp. 351-360, 2009.

[16] S. Sjostedt and E. Bezak, "Non-targeted effects of ionising radiation and radiotherapy," Australasian Physical and Engineering Sciences in Medicine, vol. 33, no. 3, pp. 219-231, 2010.

[17] B. J. Blyth and P. J. Sykes, "Radiation-induced bystander effects: what are they, and how relevant are they to human radiation exposures?" Radiation Research, vol. 176, no. 2, pp. 139-157, 2011.

[18] D. M. Spitkovskiĭ, N. N. Veǔko, A. V. Ermakov et al., "Structural and functional changing induced by exposure to adaptive doses of X-rays in the human lymphocytes both normal and defective by reparation of DNA double strands breaks," Radiation Biology, Radioecology, vol. 43, no. 2, pp. 136-143, 2003.

[19] N. N. Veĭko, A. V. Ermakov, N. A. Egolina et al., "Activation of total and ribosomal RNA transcription under adapting doses of ionizing radiation inducing displacement of chromosome loci in human Go-lymphocyte," Radiatsionnaya Biologiya. Radioekologiya, vol. 44, no. 5, pp. 501-508, 2004.

[20] A. V. Ermakov, S. V. Kostiuk, N. A. Egolina, E. M. Malinovskaia, N. N. Veǐko, and D. M. Spitkovskiı̌, "The DNA fragments obtained from the culture media exposed to adaptive doses of the ionizing radiation as factors of stress signaling between lymphocytes and bystander cells," Radiatsionnaia Biologiia, Radioecologiia, vol. 47, no. 2, pp. 133-140, 2007.

[21] S. V. Kostiuk, I. A. Zamulaeva, R. K. Agapova et al., "The changing of cell-free DNA properties of peripheral blood and TCR-mutant cell frequency in individuals exposed to ionizing radiation," Radiatsionnaia Biologiia, Radioecologiia, vol. 48, no. 1, pp. 5-13, 2008.

[22] A. V. Ermakov, S. V. Kostyuk, M. S. Kon'kova, N. A. Egolina, E. M. Malinovskaya, and N. N. Veiko, "Extracellular DNA fragments: factors of stress signaling between X-irradiated and nonirradiated human lymphocytes," Annals of the New York Academy of Sciences, vol. 1137, pp. 41-46, 2008.

[23] A. V. Ermakov, M. S. Kon’kova, S. V. Kostyuk, N. A. Egolina, L. V. Efremova, and N. N. Veiko, "Oxidative stress as a significant factor for development of an adaptive response in irradiated and nonirradiated human lymphocytes after inducing the bystander effect by low-dose X-radiation," Mutation Research, vol. 669, no. 1-2, pp. 155-161, 2009.

[24] A. V. Ermakov, M. S. Kon'kova, S. V. Kostiuk et al., "CpG-DNA inhibits cell reactions accompanied with the development of the adaptive response in human lymphocytes after low-dose X-ray exposure," Radiation Biology, Radioecology, vol. 49, no. 1, pp. 3441, 2009.

[25] A. V. Ermakov, M. S. Kon'kova, S. V. Kostiuk et al., "The response of human cancer stem cells on low-dose X-ray exposure," Radiatsionnaia Biologiia, Radioecologiia, vol. 49, no. 5, pp. 528$537,2009$.

[26] A. V. Ermakov, M. S. Kon'kova, S. V. Kostiuk et al., "Bystander effect development in human mesenchymal stem cells after exposure to adaptive dose of X-radiation," Radiatsionnaia Biologiia, Radioecologiia, vol. 50, no. 1, pp. 42-51, 2010.

[27] M. S. Kon'kova, A. V. Ermakov, L. V. Efremova, S. V. Kostyuk, and N. N. Veiko, "Influence of X-ray and/or CpG-DNA induced oxidative stress on adaptive response in human lymphocytes," International Journal of Low Radiation, vol. 7, no. 6, pp. 446452, 2010.

[28] L. V. Efremova, A. Y. Alekseeva, M. S. Kon’kova et al., "Extracellular DNA affects NO content in human endothelial cells," Bulletin of Experimental Biology and Medicine, vol. 149, no. 2, pp. 196-200, 2010.

[29] S. V. Kostyuk, T. D. Smirnova, L. V. Efremova et al., "Enhanced expression of iNOS in human endothelial cells during longterm culturing with extracellular DNA fragments," Bulletin of Experimental Biology and Medicine, vol. 149, no. 2, pp. 191-195, 2010.

[30] A. V. Ermakov, M. S. Kon'kova, S. V. Kostyuk et al., "An extracellular DNA mediated bystander effect produced from low dose irradiated endothelial cells," Mutation Research, vol. 712, no. 1-2, pp. 1-10, 2011.

[31] A. V. Ermakov, M. S. Kon'kova, S. V. Kostyuk et al., "Development of the adaptive response and bystander effect induced by low-dose ionizing radiation in human mesenchymal stem cells," in Proceedings of the 6th International Conference on Circulating Nucleic Acids in Plasma and Serum (CNAPS '11), pp. 225-231, 2011.

[32] K. V. Glebova, I. L. Konorova, A. V. Marakhonov, I. V. Barskov, L. G. Khaspekov, and N. N. Veiko, "Oxidative modification of ecDNA alter its biological action on rat neurons," Journal of Nucleic Acids Investigation, vol. 2, no. 1, p. 28, 2011.

[33] P. Loseva, S. Kostyuk, E. Malinovskaya et al., "Extracellular DNA oxidation stimulates activation of NRF2 and reduces the production of ROS in human mesenchymal stem cells," Expert Opinion on Biological Therapy, vol. 12, supplement 1, pp. 85-97, 2012.

[34] S. V. Kostyuk, A. V. Ermakov, A. Y. Alekseeva et al., "Role of extracellular DNA oxidative modification in radiation induced bystander effects in human endotheliocytes," Mutation Research, vol. 729, no. 1-2, pp. 52-60, 2012.

[35] S. Kostjuk, P. Loseva, O. Chvartatskaya et al., "Extracellular GC-rich DNA activates TLR9- and NF- $\kappa$ B-dependent signaling pathways in human adipose-derived mesenchymal stem cells (haMSCs)," Expert Opinion on Biological Therapy, vol. 12, supplement 1, pp. 99-111, 2012.

[36] M. T. Russo, M. F. Blasi, F. Chiera et al., "The oxidized deoxynucleoside triphosphate pool is a significant contributor to genetic instability in mismatch repair-deficient cells," Molecular and Cellular Biology, vol. 24, no. 1, pp. 465-474, 2004.

[37] E. Speina, K. D. Arczewska, D. Gackowski et al., "Contribution of hMTH1 to the maintenance of 8-oxoguanine levels in lung DNA of non-small-cell lung cancer patients," Journal of the National Cancer Institute, vol. 97, no. 5, pp. 384-395, 2005.

[38] D. Mangal, D. Vudathala, J. Park, H. L. Seon, T. M. Penning, and I. A. Blair, "Analysis of 7,8-dihydro-8-oxo-2'-deoxyguanosine 
in cellular DNA during oxidative stress," Chemical Research in Toxicology, vol. 22, no. 5, pp. 788-797, 2009.

[39] J. Ravanat, T. Douki, P. Duez et al., "Cellular background level of 8-oxo-7,8-dihydro-2' -deoxyguanosine: an isotope based method to evaluate artefactual oxidation of DNA during its extraction and subsequent work-up," Carcinogenesis, vol. 23, no. 11, pp. 1911-1918, 2002.

[40] D. Li, W. Zhang, J. Zhu et al., "Oxidative DNA damage and 8hydroxy-2-deoxyguanosine DNA glycosylase/apurinic lyase in human breast cancer," Molecular Carcinogenesis, vol. 31, no. 4, pp. 214-223, 2001.

[41] E. S. Hwang and P. E. Bowen, "DNA damage, a biomarker of carcinogenesis: its measurement and modulation by diet and environment," Critical Reviews in Food Science and Nutrition, vol. 47, no. 1, pp. 27-50, 2007.

[42] A. Valavanidis, T. Vlachogianni, and C. Fiotakis, "8-hydroxy-2' -deoxyguanosine (8-OHdG): a critical biomarker of oxidative stress and carcinogenesis," Journal of Environmental Science and Health C, Environmental Carcinogenesis \& Ecotoxicology Reviews, vol. 27, no. 2, pp. 120-139, 2009.

[43] S. Loft, P. Møller, M. S. Cooke, R. Rozalski, and R. Olinski, "Antioxidant vitamins and cancer risk: is oxidative damage to DNA a relevant biomarker?" European Journal of Nutrition, vol. 47, no. 2, pp. 19-28, 2008.

[44] D. C. Malins and R. Haimanot, "Major alterations in the nucleotide structure of DNA in cancer of the female breast," Cancer Research, vol. 51, no. 19, pp. 5430-5432, 1991.

[45] A. Matsui, T. Ikeda, K. Enomoto et al., "Increased formation of oxidative DNA damage, 8-hydroxy-2' - deoxyguanosine, in human breast cancer tissue and its relationship to GSTP1 and COMT genotypes," Cancer Letters, vol. 151, no. 1, pp. 87-95, 2000.

[46] J. Musarrat, J. Arezina-Wilson, and A. A. Wani, "Prognostic and aetiological relevance of 8-hydroxyguanosine in human breast carcinogenesis," European Journal of Cancer A, vol. 32, no. 7, pp. 1209-1214, 1996.

[47] E. Gajewski, S. Gaur, S. A. Akman, L. Matsumoto, J. N. A. van Balgooy, and J. H. Doroshow, "Oxidative DNA base damage in MCF-10A breast epithelial cells at clinically achievable concentrations of doxorubicin," Biochemical Pharmacology, vol. 73, no. 12, pp. 1947-1956, 2007.

[48] D. C. Malins, P. M. Johnson, T. M. Wheeler et al., "Age-related radical-induced DNA damage is linked to prostate cancer," Cancer Research, vol. 61, no. 16, pp. 6025-6028, 2001.

[49] D. C. Malins, P. M. Johnson, E. A. Barker, N. L. Polissar, T. M. Wheeler, and K. M. Anderson, "Cancer-related changes in prostate DNA as men age and early identification of metastasis in primary prostate tumors," Proceedings of the National Academy of Sciences of the United States of America, vol. 100, no. 9, pp. 5401-5406, 2003.

[50] S. Pathak, R. Singh, R. D. Verschoyle et al., "Androgen manipulation alters oxidative DNA adduct levels in androgen-sensitive prostate cancer cells grown in vitro and in vivo," Cancer Letters, vol. 261, no. 1, pp. 74-83, 2008.

[51] M. Sanchez, J. V. Torres, C. Tormos et al., "Impairment of antioxidant enzymes, lipid peroxidation and 8-oxo- $2^{\prime}$-deoxyguanosine in advanced epithelial ovarian carcinoma of a Spanish community," Cancer Letters, vol. 233, no. 1, pp. 28-35, 2006.

[52] M. Foksinski, R. Kotzbach, W. Szymanski, and R. Olinski, "The level of typical biomarker of oxidative stress 8-hydroxy-2' deoxyguanosine is higher in uterine myomas than in control tissues and correlates with the size of the tumor," Free Radical Biology and Medicine, vol. 29, no. 7, pp. 597-601, 2000.

[53] P. Jaruga, T. H. Zastawny, J. Skokowski, M. Dizdaroglu, and R. Olinski, "Oxidative DNA base damage and antioxidant enzyme activities in human lung cancer," The FEBS Letters, vol. 341, no. 1, pp. 59-64, 1994.

[54] R. Olinski, T. Zastawny, J. Budzbon, J. Skokowski, W. Zegarski, and M. Dizdaroglu, "DNA base modifications in chromatin of human cancerous tissues," The FEBS Letters, vol. 309, no. 2, pp. 193-198, 1992.

[55] K. Roszkowski, W. Jozwicki, P. Blaszczyk, A. Mucha-Malecka, and A. Siomek, "Oxidative damage DNA: 8-oxogua and 8oxodG as molecular markers of cancer," Medical Science Monitor, vol. 17, no. 6, pp. CR329-CR333, 2011.

[56] S. Lagadu, M. Lechevrel, F. Sichel et al., "8-oxo-7,8-dihydro-2' deoxyguanosine as a biomarker of oxidative damage in oesophageal cancer patients: lack of association with antioxidant vitamins and polymorphism of hOGG1 and GST," Journal of Experimental and Clinical Cancer Research, vol. 29, no. 1, pp. 157-167, 2010.

[57] A. Szaflarska-Popławska, A. Siomek, M. Czerwionka-Szaflarska et al., "Oxidatively damaged DNA/oxidative stress in children with celiac disease," Cancer Epidemiology Biomarkers and Prevention, vol. 19, no. 8, pp. 1960-1965, 2010.

[58] R. Gnana Oli, G. Fazeli, W. Kuhn, S. Walitza, M. Gerlach, and H. Stopper, "No increased chromosomal damage in 1-DOPAtreated patients with Parkinson's disease: a pilot study," Journal of Neural Transmission, vol. 117, no. 6, pp. 737-746, 2010.

[59] T. Dziaman, T. Huzarski, D. Gackowski et al., "Selenium supplementation reduced oxidative DNA damage in adnexectomized BRCA1 mutations carriers," Cancer Epidemiology Biomarkers and Prevention, vol. 18, no. 11, pp. 2923-2928, 2009.

[60] J. Guz, M. Foksinski, A. Siomek et al., "The relationship between 8-oxo-7,8-dihydro-2' -deoxyguanosine level and extent of cytosine methylation in leukocytes DNA of healthy subjects and in patients with colon adenomas and carcinomas," Mutation Research, vol. 640, no. 1-2, pp. 170-173, 2008.

[61] S. V. Vulimiri, X. Wu, W. Baer-Dubowska, M. de Andrade et al., "Analysis of aromatic DNA adducts and 7,8-dihydro-8-oxo2 -deoxyguanosine in lymphocyte DNA from a case-control study of lung cancer involving minority populations," Molecular Carcinogenesis, vol. 27, no. 1, pp. 34-46, 2000.

[62] M. Yen, S. Kao, A. Wang, and Y. Wei, "Increased 8-hydroxy-2' deoxyguanosine in leukocyte DNA in Leber's hereditary optic neuropathy," Investigative Ophthalmology and Visual Science, vol. 45, no. 6, pp. 1688-1691, 2004.

[63] A. Kikuchi, A. Takeda, H. Onodera et al., "Systemic increase of oxidative nucleic acid damage in Parkinson's disease and multiple system atrophy," Neurobiology of Disease, vol. 9, no. 2, pp. 244-248, 2002.

[64] L. Haider, M. T. Fischer, J. M. Frischer et al., "Oxidative damage in multiple sclerosis lesions," Brain, vol. 134, no. 7, pp. 1914-1924, 2011.

[65] L. Lyras, N. J. Cairns, A. Jenner, P. Jenner, and B. Halliwell, "An assessment of oxidative damage to proteins, lipids, and DNA in brain from patients with Alzheimer's disease," Journal of Neurochemistry, vol. 68, no. 5, pp. 2061-2069, 1997.

[66] N. Nishioka and S. E. Arnold, "Evidence for oxidative DNA damage in the hippocampus of elderly patients with chronic schizophrenia," The American Journal of Geriatric Psychiatry, vol. 12, no. 2, pp. 167-175, 2004. 
[67] D. Tarng, T. Huang, Y. Wei et al., "8-Hydroxy-2' -deoxyguanosine of leukocyte DNA as a marker of oxidative stress in chronic hemodialysis patients," American Journal of Kidney Diseases, vol. 36, no. 5, pp. 934-944, 2000.

[68] D. C. Tarng, T. P. Huang, T. Y. Liu et al., "Effect of vitamin Ebonded membrane on the 8-hydroxy $2^{\prime}$-deoxyguanosine level in leukocyte DNA of hemodialysis patients," Kidney International, vol. 58, no. 2, pp. 790-799, 2000.

[69] D. Tarng, T. W. Chen, T. Huang, C. Chen, T. Liu, and Y. Wei, "Increased oxidative damage to peripheral blood leukocyte DNA in chronic peritoneal dialysis patients," Journal of the American Society of Nephrology, vol. 13, no. 5, pp. 1321-1330, 2002.

[70] G. Pagano, P. Degan, M. d'Ischia et al., "Gender- and age-related distinctions for the in vivo prooxidant state in Fanconi anaemia patients," Carcinogenesis, vol. 25, no. 10, pp. 1899-1909, 2004.

[71] I. M. Agbaje, C. M. McVicar, B. C. Schock et al., "Increased concentrations of the oxidative DNA adduct 7,8-dihydro-8-oxo2-deoxyguanosine in the germ-line of men with type 1 diabetes," Reproductive BioMedicine Online, vol. 16, no. 3, pp. 401-409, 2008.

[72] S. Yurdakul, B. Ozben, A. K. Bilge, U. M. Turkoglu, S. Arkaya, and Y. Nisanci, "Oxidative DNA damage is significantly correlated with flow-mediated dilation in patients with coronary artery disease," Journal of Investigative Medicine, vol. 56, no. 7, pp. 925-930, 2008.

[73] M. Satoh, Y. Minami, Y. Takahashi, T. Tabuchi, T. Itoh, and M. Nakamura, "Effect of intensive lipid-lowering therapy on telomere erosion in endothelial progenitor cells obtained from patients with coronary artery disease," Clinical Science, vol. 116, no. 11-12, pp. 827-835, 2009.

[74] T. Kaneko, S. Tahara, and M. Matsuo, "Non-linear accumulation of 8-hydroxy-2'-deoxyguanosine, a marker of oxidized DNA damage, during aging," Mutation Research, vol. 316, no. 5-6, pp. 277-285, 1996.

[75] T. Kaneko, S. Tahara, and M. Matsuo, "Retarding effect of dietary restriction on the accumulation of 8-hydroxy-2' deoxyguanosine in organs of Fischer 344 rats during aging," Free Radical Biology and Medicine, vol. 23, no. 1, pp. 76-81, 1997.

[76] C. G. Fraga, M. K. Shigenaga, J. W. Park, P. Degan, and B. N. Ames, "Oxidative damage to DNA during aging: 8-hydroxy-2' deoxyguanosine in rat organ DNA and urine," Proceedings of the National Academy of Sciences of the United States of America, vol. 87, no. 12, pp. 4533-4537, 1990.

[77] A. Siomek, D. Gackowski, R. Rozalski et al., "Higher leukocyte 8-oxo-7,8-dihydro-2' -deoxyguanosine and lower plasma ascorbate in aging humans?" Antioxidants and Redox Signaling, vol. 9, no. 1, pp. 143-150, 2007.

[78] T. Kaneko, S. Tahara, T. Taguchi, and H. Kondo, "Accumulation of oxidative DNA damage, 8-oxo-2'-deoxyguanosine, and change of repair systems during in vitro cellular aging of cultured human skin fibroblasts," Mutation Research, vol. 487, no. 1-2, pp. 19-30, 2001.

[79] Y. Homma, M. Tsunoda, and H. Kasai, "Evidence for the accumulation of oxidative stress during cellular ageing of human diploid fibroblasts," Biochemical and Biophysical Research Communications, vol. 203, no. 2, pp. 1063-1068, 1994.

[80] S. Hajizadeh, J. DeGroot, J. M. TeKoppele, A. Tarkowski, and L. V. Collins, "Extracellular mitochondrial DNA and oxidatively damaged DNA in synovial fluid of patients with rheumatoid arthritis," Arthritis Research \& Therapy, vol. 5, no. 5, pp. R234R240, 2003.
[81] B. Zhang, A. Angelidou, K. D. Alysandratos et al., "Mitochondrial DNA and anti-mitochondrial antibodies in serum of autistic children," Journal of Neuroinflammation, vol. 7, pp. 8085, 2010.

[82] A. Cossarizza, M. Pinti, M. Nasi et al., "Increased plasma levels of extracellular mitochondrial DNA during HIV infection: a new role for mitochondrial damage-associated molecular patterns during inflammation," Mitochondrion, vol. 11, no. 5, pp. 750-755, 2011.

[83] E. M. Malinovskaya, T. D. Smirnova, N. A. Egolina et al., "Changes in human ribosomal genes ensemble with ageing," Medical Genetics, vol. 7, no. 2, pp. 10-16, 2008.

[84] M. Fleischhacker and B. Schmidt, "Circulating nucleic acids (CNAs) and cancer-a survey," Biochimica et Biophysica Acta, vol. 1775, no. 1, pp. 181-232, 2007.

[85] S. Jahr, H. Hentze, S. Englisch et al., "DNA fragments in the blood plasma of cancer patients: quantitations and evidence for their origin from apoptotic and necrotic cells," Cancer Research, vol. 61, no. 4, pp. 1659-1665, 2001.

[86] M. van der Vaart and P. J. Pretorius, "Circulating DNA: its origin and fluctuation," Annals of the New York Academy of Sciences, vol. 1137, pp. 18-26, 2008.

[87] G. Sozzi, D. Conte, L. Mariani et al., "Analysis of circulating tumor DNA in plasma at diagnosis and during follow-up of lung cancer patients," Cancer Research, vol. 61, no. 12, pp. 4675-4678, 2001.

[88] J. Jylhävä, M. Jylhä, T. Lehtimäki, A. Hervonen, and M. Hurme, "Circulating cell-free DNA is associated with mortality and inflammatory markers in nonagenarians: the Vitality $90+$ Study," Experimental Gerontology, vol. 47, no. 5, pp. 372-378, 2012.

[89] J. Atamaniuk, C. Vidotto, M. Kinzlbauer, N. Bachl, B. Tiran, and $\mathrm{H}$. Tschan, "Cell-free plasma DNA and purine nucleotide degradation markers following weightlifting exercise," European Journal of Applied Physiology, vol. 110, no. 4, pp. 695-701, 2010.

[90] S. Hahn, C. Rusterholz, I. Hösli, and O. Lapaire, "Cell-free nucleic acids as potential markers for preeclampsia," Placenta, vol. 32, no. 1, pp. S17-S20, 2011.

[91] I. L. Konorova and N. N. Veiko, "Emotional stress in rats changes concentration and composition of extracellular DNA circulating in blood plasma under normal conditions and in cerebral ischemia," Bulletin of Experimental Biology and Medicine, vol. 153, no. 3, pp. 305-308, 2012.

[92] N. N. Veĭko, N. V. Bulycheva, O. A. Roginko et al., "Ribosomal repeat in cell free DNA as a marker for cell death," Biochemistry (Moscow) Supplement Series B: Biomedical Chemistry, vol. 2, no. 2, pp. 198-207, 2008.

[93] C. Wang, N. Yang, C. Chang, S. Liou, and H. Lee, "Rapid and simple one-step membrane extraction for the determination of 8 -hydroxy-2' -deoxyguanosine in human plasma by a combination of on-line solid phase extraction and LC-MS/MS," Journal of Chromatography B: Analytical Technologies in the Biomedical and Life Sciences, vol. 879, no. 30, pp. 3538-3543, 2011.

[94] C. Hu, Y. Huang, Y. Li, and M. Chao, "Correlation between concentrations of 8-oxo-7,8-dihydro- $2^{\prime}$-deoxyguanosine in urine, plasma and saliva measured by on-line solid-phase extraction LC-MS/MS," Clinica Chimica Acta, vol. 411, no. 17-18, pp. 12181222, 2010.

[95] R. A. El-Zein, C. M. Monroy, A. Cortes, M. R. Spitz, A. Greisinger, and C. J. Etzel, "Rapid method for determination of 
DNA repair capacity in human peripheral blood lymphocytes amongst smokers," BMC Cancer, vol. 10, pp. 439-448, 2010.

[96] C. S. Shin, B. S. Moon, K. S. Park et al., "Serum 8-hydroxyguanine levels are increased in diabetic patients," Diabetes Care, vol. 24, no. 4, pp. 733-737, 2001.

[97] Z. Hamurcu, F. Bayram, G. Kahriman, H. Dönmez-Altuntas, and G. Baskol, "Micronucleus frequency in lymphocytes and 8-hydroxydeoxyguanosine level in plasma of women with polycystic ovary syndrome," Gynecological Endocrinology, vol. 26, no. 8, pp. 590-595, 2010.

[98] H. Pan, H. Zhang, D. Chang, H. Li, and H. Sui, "The change of oxidative stress products in diabetes mellitus and diabetic retinopathy," British Journal of Ophthalmology, vol. 92, no. 4, pp. 548-551, 2008.

[99] R. J. Bloomer and K. H. Fisher-Wellman, "Blood oxidative stress biomarkers: influence of sex, exercise training status, and dietary intake," Gender Medicine, vol. 5, no. 3, pp. 218-228, 2008.

[100] M. S. Cooke, R. Singh, G. K. Hall et al., "Evaluation of enzymelinked immunosorbent assay and liquid chromatographytandem mass spectrometry methodology for the analysis of 8oxo-7,8-dihydro- $2^{\prime}$-deoxyguanosine in saliva and urine," Free Radical Biology and Medicine, vol. 41, no. 12, pp. 1829-1836, 2006.

[101] D. Chang, Q. Sha, X. Zhang et al., "The evaluation of the oxidative stress parameters in patients with primary angleclosure glaucoma," PLoS ONE, vol. 6, no. 11, Article ID e27218, 2011.

[102] E. M. Park, M. K. Shigenaga, P. Degan et al., "Assay of excised oxidative DNA lesions: isolation of 8-oxoguanine and its nucleoside derivatives from biological fluids with a monoclonal antibody column," Proceedings of the National Academy of Sciences of the United States of America, vol. 89, no. 8, pp. 33753379, 1992.

[103] M. B. Bogdanov, M. F. Beal, D. R. McCabe, R. M. Griffin, and W. R. Matson, "A carbon column-based liquid chromatography electrochemical approach to routine 8-hydroxy2 -deoxyguanosine measurements in urine and other biologic matrices: a one-year evaluation of methods," Free Radical Biology and Medicine, vol. 27, no. 5-6, pp. 647-666, 1999.

[104] N. N. Veiko, N. O. Shubaeva, S. M. Ivanova, A. I. Speranskii, N. A. Lyapunova, and D. M. Spitkovskii, "Blood serum DNA in patients with rheumatoid arthritis is considerably enriched with fragments of ribosomal repeats containing immunostimulatory CpG-motifs," Bulletin of Experimental Biology and Medicine, vol. 142, no. 3, pp. 313-316, 2006.

[105] N. N. Veĭko and D. M. Spitkovskiŭ, "The accumulation of single-stranded breaks does not lead to paired DNA damagethe characteristic of the transcribing fragment of the human ribosomal operon that allows its being detected in biological fluids at the death of different body cells," Radiation Biology, Radioecology, vol. 40, no. 4, pp. 396-404, 2000.

[106] E. S. Morozkin, E. M. Loseva, I. V. Morozov et al., "A comparative study of cell-free apoptotic and genomic DNA using FISH and massive parallel sequencing," Expert Opinion on Biological Therapy, vol. 12, supplement 1, pp. 11-17, 2012.

[107] M. Suter and C. Richter, "Fragmented mitochondrial DNA is the predominant carder of oxidized DNA bases," Biochemistry, vol. 38, no. 1, pp. 459-464, 1999.

[108] N. Bulicheva, O. Fidelina, N. Mkrtumova et al., "Effect of cell-free DNA of patients with cardiomyopathy and rDNA on the frequency of contraction of electrically paced neonatal rat ventricular myocytes in culture," Annals of the New York Academy of Sciences, vol. 1137, pp. 273-277, 2008.

[109] H. Yoshida, M. Nishikawa, T. Kiyota, H. Toyota, and Y. Takakura, "Increase in CpG DNA-induced inflammatory responses by DNA oxidation in macrophages and mice," Free Radical Biology and Medicine, vol. 51, no. 2, pp. 424-431, 2011.

[110] H. Ahsan, A. Ali, and R. Ali, "Oxygen free radicals and systemic autoimmunity," Clinical and Experimental Immunology, vol. 131, no. 3, pp. 398-404, 2003.

[111] M. S. Cooke, K. E. Herbert, P. C. Butler, and J. Lunec, "Further evidence for a possible role of conformation in the immunogenicity and antigenicity of the oxidative DNA lesion, 8-oxo2 'deoxyguanosine," Free Radical Research, vol. 28, no. 5, pp. 459-469, 1998.

[112] A. V. Ermakov, N. I. Pospekhova, and D. M. Spitkovskil̆, "Subpopulation of lymphocytes in peripheral human blood responds to the action of low doses of ionizing radiation and interleukine-2 and also to the action of both factors," Radiatsionnaya Biologiya. Radioekologiya, vol. 40, no. 1, pp. 62-70, 2000.

[113] W. M. Bonner, "Low-dose radiation: ahresholds, bystander effects, and adaptive responses," Proceedings of the National Academy of Sciences of the United States of America, vol. 100, no. 9, pp. 4973-4975, 2003.

[114] W. F. Morgan, A. Hartmann, C. L. Limoli, S. Nagar, and B. Ponnaiya, "Bystander effects in radiation-induced genomic instability," Mutation Research, vol. 504, no. 1-2, pp. 91-100, 2002.

[115] J. K. Leach, G. van Tuyle, P. S. Lin, R. Schmidt-Ullrich, and R. B. Mikkelsen, "Ionizing radiation-induced, mitochondriadependent generation of reactive oxygen/nitrogen," Cancer Research, vol. 61, no. 10, pp. 3894-3901, 2001.

[116] M. Dizdaroglu, "Oxidative damage to DNA in mammalian chromatin," Mutation Research, vol. 275, no. 3-6, pp. 331-342, 1992.

[117] A. P. Breen and J. A. Murphy, "Reactions of oxyl radicals with DNA," Free Radical Biology and Medicine, vol. 18, no. 6, pp. 10331077, 1995.

[118] J. Cadet, T. Delatour, T. Douki et al., "Hydroxyl radicals and DNA base damage," Mutation Research, vol. 424, no. 1-2, pp. 921, 1999.

[119] J. Cadet, T. Douki, D. Gasparutto, and J. Ravanat, "Oxidative damage to DNA: formation, measurement and biochemical features," Mutation Research, vol. 531, no. 1-2, pp. 5-23, 2003.

[120] S. Burney, J. L. Caulfield, J. C. Niles, J. S. Wishnok, and S. R. Tannenbaum, "The chemistry of DNA damage from nitric oxide and peroxynitrite," Mutation Research, vol. 424, no. 1-2, pp. 3749, 1999.

[121] S. Kawanishi, Y. Hiraku, and S. Oikawa, "Mechanism of guanine-specific DNA damage by oxidative stress and its role in carcinogenesis and aging," Mutation Research, vol. 488, no. 1, pp. 65-76, 2001.

[122] C. Chatgilialoglu and P. O.'Neill, "Free radicals associated with DNA damage," Experimental Gerontology, vol. 36, no. 9, pp. 1459-1471, 2001.

[123] N. Hamada, G. Schettino, G. Kashino et al., "Histone H2AX phosphorylation in normal human cells irradiated with focused ultrasoft $\mathrm{X}$ rays: evidence for chromatin movement during repair," Radiation Research, vol. 166, no. 1, part 1, pp. 31-38, 2006.

[124] M. Gandhi, V. N. Evdokimova, K. T. Cuenco et al., "Homologous chromosomes make contact at the sites of doublestrand breaks in genes in somatic G0/G1-phase human cells," 
Proceedings of the National Academy of Sciences of the United States of America, vol. 109, no. 24, pp. 9454-9459, 2012.

[125] F. M. Lyng, C. B. Seymour, and C. Mothersill, "Early events in the apoptotic cascade initiated in cells treated with medium from the progeny of irradiated cells," Radiation Protection Dosimetry, vol. 99, no. 1-4, pp. 169-172, 2002.

[126] G. Hartmann and A. M. Krieg, "Mechanism and function of a newly identified CpG DNA motif in human primary B cells," The Journal of Immunology, vol. 164, no. 2, pp. 944-952, 2000.

[127] L. József, T. Khreiss, D. El Kebir, and J. G. Filep, “Activation of TLR-9 induces IL-8 secretion through peroxynitrite signaling in human neutrophils," The Journal of Immunology, vol. 176, no. 2, pp. 1195-1202, 2006.

[128] J. A. Pedras-Vasconcelos, D. Goucher, M. Puig et al., "CpG oligodeoxynucleotides protect newborn mice from a lethal challenge with the neurotropic Tacaribe arenavirus," The Journal of Immunology, vol. 176, no. 8, pp. 4940-4949, 2006.

[129] P. Henneke, O. Takeuchi, R. Malley et al., "Cellular activation, phagocytosis, and bactericidal activity against group $\mathrm{B}$ streptococcus involve parallel myeloid differentiation factor 88dependent and independent signaling pathways," The Journal of Immunology, vol. 169, no. 7, pp. 3970-3977, 2002.

[130] Y. Adachi, A. L. Kindzelskii, A. R. Petty et al., "IFN- $\gamma$ primes RAW264 macrophages and human monocytes for enhanced oxidant production in response to $\mathrm{CpG}$ DNA via metabolic signaling: roles of TLR9 and myeloperoxidase trafficking," The Journal of Immunology, vol. 176, no. 8, pp. 5033-5040, 2006.

[131] H. Matsumoto, N. Hamada, A. Takahashi, Y. Kobayashi, and T. Ohnishi, "Vanguards of paradigm shift in radiation biology: radiation-induced adaptive and bystander responses," Journal of Radiation Research, vol. 48, no. 2, pp. 97-106, 2007.

[132] D. Tang, M. T. Lotze, H. J. Zeh, and R. Kang, "The redox protein HMGB1 regulates cell death and survival in cancer treatment," Autophagy, vol. 6, no. 8, pp. 1181-1183, 2010.

[133] H. Zhang, X. Gao, J. Zhao et al., "Differential gene expression profiles of DNA repair genes in esophageal cancer cells after Xray irradiation," Chinese Journal of Cancer, vol. 29, no. 10, pp. 865-872, 2010.

[134] M. L. Brezniceanu, K. Volp, S. Bosser et al., "HMGB1 inhibits cell death in yeast and mammalian cells and is abundantly expressed in human breast carcinoma," The FASEB Journal, vol. 17, no. 10, pp. 1295-1297, 2003.

[135] T. E. Schmid and G. Multhoff, "Radiation-induced stress proteins - the role of heat shock proteins (HSP) in anti-tumor responses," Current Medicinal Chemistry, vol. 19, no. 12, pp. 1765-1770, 2012.

[136] Y. Suzuki, K. Mimura, Y. Yoshimoto et al., "Immunogenic tumor cell death induced by chemoradiotherapy in patients with esophageal squamous cell carcinoma," Cancer Research, vol. 72, no. 16, pp. 3967-3976, 2012.

[137] J. Tian, A. M. Avalos, S. Y. Mao et al., “Toll-like receptor 9dependent activation by DNA-containing immune complexes is mediated by HMGB1 and RAGE," Nature Immunology, vol. 8, no. 5, pp. 487-496, 2007.

[138] S. Ivanov, A. Dragoi, X. Wang et al., "A novel role for HMGB1 in TLR9-mediated inflammatory responses to CpG-DNA," Blood, vol. 110, no. 6, pp. 1970-1981, 2007.

[139] M. E. Bianchi, "HMGB1 loves company," Journal of Leukocyte Biology, vol. 86, no. 3, pp. 573-576, 2009.
[140] H. S. Hreggvidsdottir, T. Östberg, H. Wähämaa et al., “The alarmin HMGB1 acts in synergy with endogenous and exogenous danger signals to promote inflammation," Journal of Leukocyte Biology, vol. 86, no. 3, pp. 655-662, 2009.

[141] H. Yanai, T. Ban, Z. Wang et al., "HMGB proteins function as universal sentinels for nucleic-acid-mediated innate immune responses," Nature, vol. 462, no. 7269, pp. 99-103, 2009.

[142] Z. M. Bamboat, V. P. Balachandran, L. M. Ocuin, H. Obaid, G. Plitas, and R. P. DeMatteo, "Toll-like receptor 9 inhibition confers protection from liver ischemia-reperfusion injury," Hepatology, vol. 51, no. 2, pp. 621-632, 2010.

[143] C. Wang, G. Fei, Z. Liu et al., "HMGB1 was a pivotal synergistic effecor for CpG oligonucleotide to enhance the progression of human lung cancer cells," Cancer Biology \& Therapy, vol. 13, no. 9, pp. 727-736, 2012.

[144] E. A. Pasheva, I. G. Pashev, and A. Favre, "Preferential binding of high mobility group 1 protein to UV-damaged DNA: role of the COOH-terminal domain," Journal of Biological Chemistry, vol. 273, no. 38, pp. 24730-24736, 1998.

[145] H. Huang, J. Evankovich, W. Yan et al., "Endogenous histones function as alarmins in sterile inflammatory liver injury through Toll-like receptor 9 in mice," Hepatology, vol. 54, no. 3, pp. 999-1008, 2011.

[146] K. Yasuda, P. Yu, C. J. Kirschning et al., "Endosomal translocation of vertebrate DNA activates dendritic cells via TLR9-dependent and -independent pathways," The Journal of Immunology, vol. 174, no. 10, pp. 6129-6136, 2005.

[147] H. Wagner and S. Bauer, "All is not Toll: new pathways in DNA recognition.," The Journal of experimental medicine, vol. 203, no. 2, pp. 265-268, 2006.

[148] V. Hornung and E. Latz, "Intracellular DNA recognition," Nature Reviews Immunology, vol. 10, no. 2, pp. 123-130, 2010.

[149] S. Wolff, "The adaptive response in radiobiology: evolving insights and implications," Environmental Health Perspectives, vol. 106, supplement 1, pp. 277-283, 1998.

[150] J. D. Shadley and S. Wolff, "Very low doses of X-rays can cause human lymphocytes to become less susceptible to ionizing radiation," Mutagenesis, vol. 2, no. 2, pp. 95-96, 1987.

[151] C. Mothersill, K. O.'Malley, and C. B. Seymour, "Characterisation of a bystander effect induced in human tissue explant cultures by low let radiation," Radiation Protection Dosimetry, vol. 99, no. 1-4, pp. 163-167, 2002.

[152] M. Buonanno, S. M. de Toledo, D. Pain, and E. I. Azzam, "Longterm consequences of radiation-induced bystander effects depend on radiation quality and dose and correlate with oxidative stress," Radiation Research, vol. 175, no. 4, pp. 405-415, 2011.

[153] K. Suzuki, M. Ojima, S. Kodama, and M. Watanabe, "Radiationinduced DNA damage and delayed induced genomic instability," Oncogene, vol. 22, no. 45, pp. 6988-6993, 2003.

[154] N. Hamada, H. Matsumoto, T. Hara, and Y. Kobayashi, "Intercellular and intracellular signaling pathways mediating ionizing radiation-induced bystander effects," Journal of Radiation Research, vol. 48, no. 2, pp. 87-95, 2007.

[155] S. Tapio and V. Jacob, "Radioadaptive response revisited," Radiation and Environmental Biophysics, vol. 46, no. 1, pp. 1-12, 2007. 


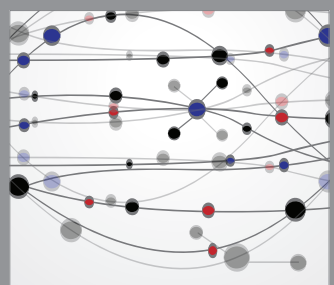

The Scientific World Journal
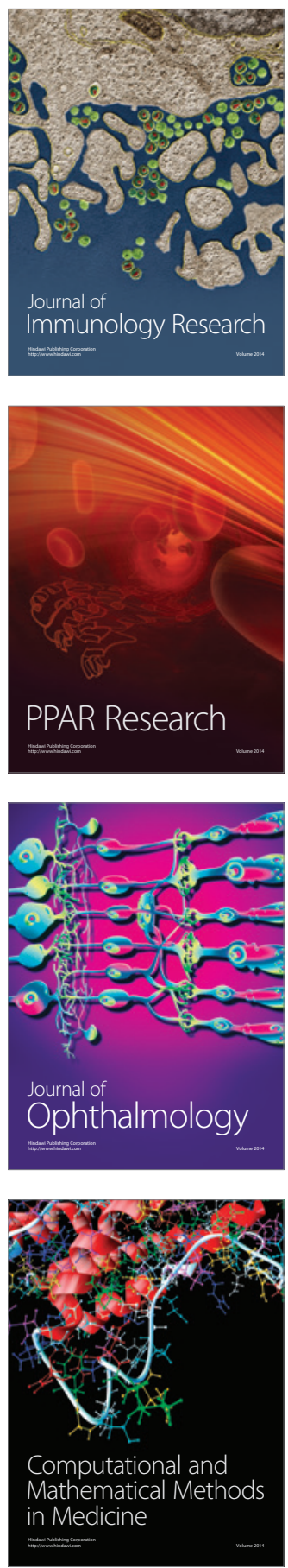

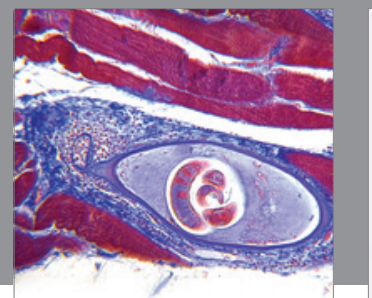

Gastroenterology

Research and Practice
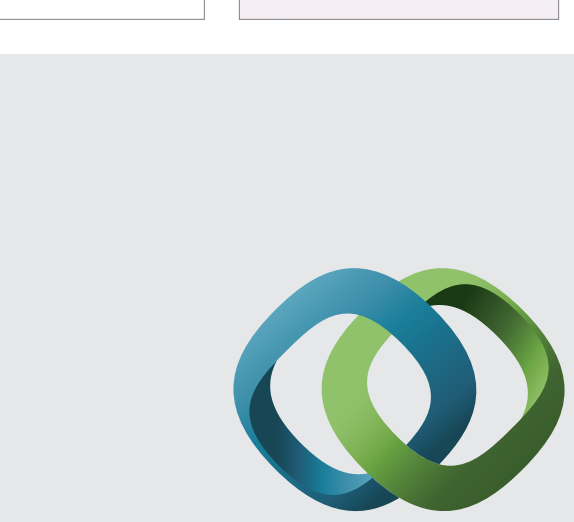

\section{Hindawi}

Submit your manuscripts at

http://www.hindawi.com
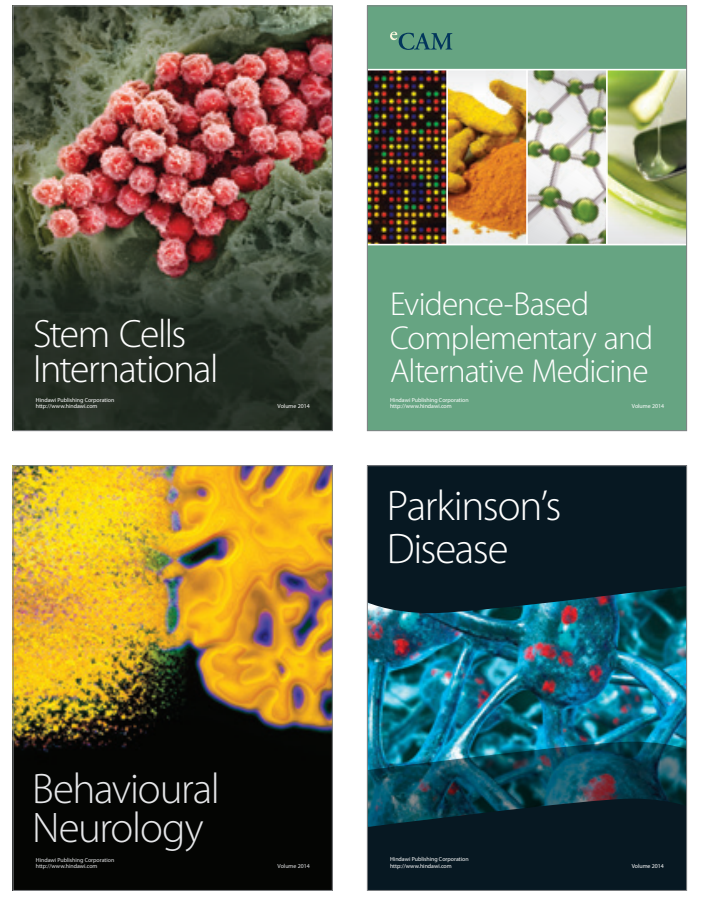
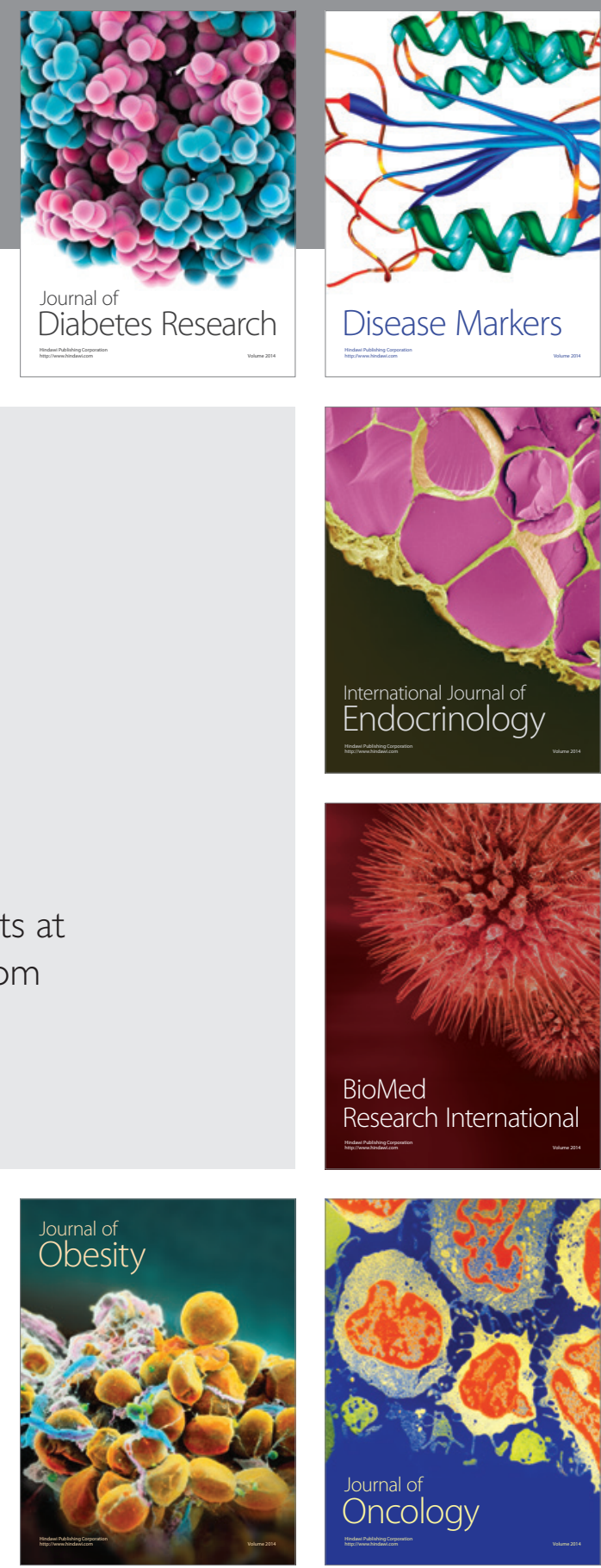

Disease Markers
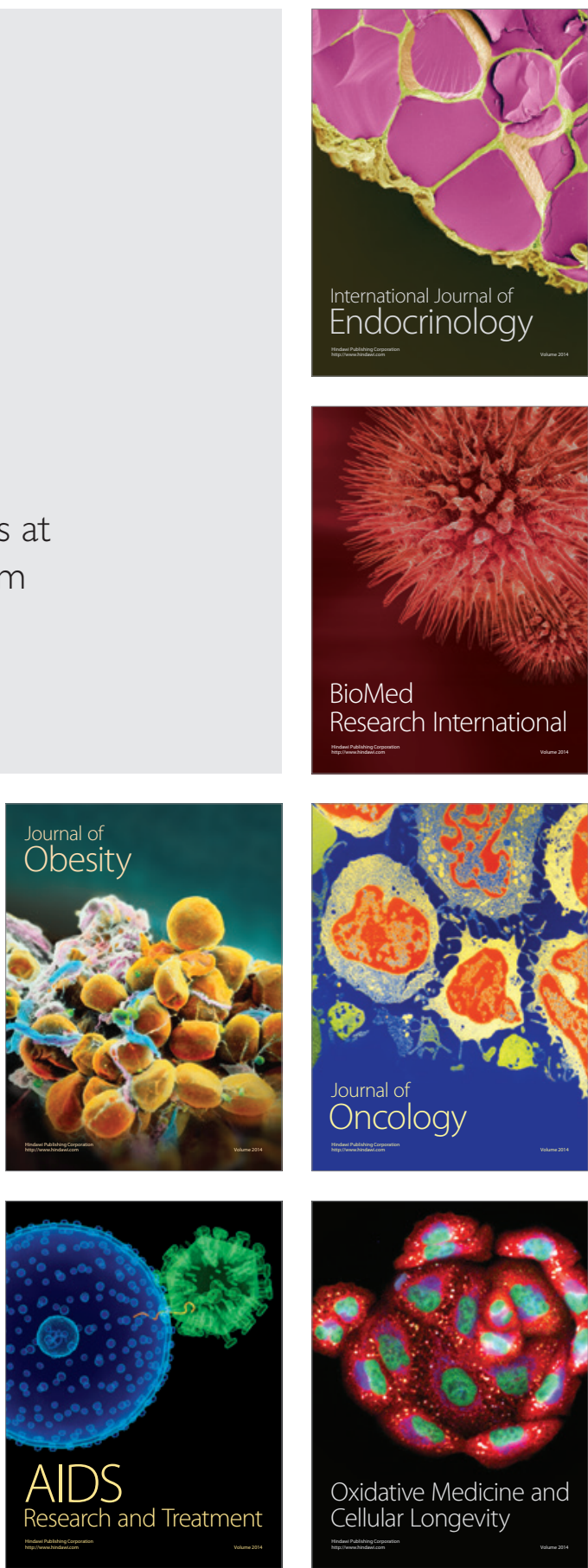